\title{
Novel IL-6-secreting $\gamma \delta$ T cells increased in patients with atherosclerotic cerebral infarction
}

\author{
YOUDI HE ${ }^{1 *}$, NING MA $^{2,3^{*}}$, CHEN XING $^{2}$, XIAOQIAN WANG ${ }^{2}$, HE XIAO $^{2}$, MINGKE ZHENG $^{2,4}$, \\ GENCHENG HAN ${ }^{2}$, GUOJIANG CHEN ${ }^{2}$, CHUNMEI HOU ${ }^{2}$, BEIFEN SHEN ${ }^{2}$, \\ ${\text { YAN } L^{2}}^{2}$, ZHENYU JIANG ${ }^{3}$ RENXI WANG ${ }^{2}$ and WENLI HU ${ }^{1}$ \\ ${ }^{1}$ Department of Neurology, Beijing Chaoyang Hospital, Capital Medical University, Beijing 100020; ${ }^{2}$ Laboratory of \\ Immunology, Institute of Basic Medical Sciences, Beijing 100850; ${ }^{3}$ Department of Rheumatology, \\ First Hospital of Jilin University, Changchun, Jilin 130021; ${ }^{4}$ Department of Immunology, \\ Medical College of Henan University, Kaifeng, Henan 475001, P.R. China
}

Received December 30, 2013; Accepted September 18, 2014

DOI: $10.3892 / \mathrm{mmr} .2014 .2796$

\begin{abstract}
Mounting evidence has suggested that inflammation associated with interleukin (IL)-6 and T-helper (Th)17 cells, has a role in the development of atherosclerotic cerebral infarction (ACI). However, it remains unclear which population of cells determines the levels of IL-6, and the role of IL-6-secreting cells in inducing Th17 cell production. In the present study, IL-6 levels were determined in patients with ACI, by ELISA. The percentage of $\mathrm{CD}^{+} \mathrm{T}, \mathrm{CD} 4^{+} \mathrm{T}, \mathrm{CD} 8^{+} \mathrm{T}$, CD $11 \mathrm{c}^{+}$dendritic cells and $\gamma \delta \mathrm{T}$ cells were determined by flow cytometry, and the correlation between cytokine IL- 6 and $\gamma \delta$ T cells was determined by statistical analysis. An in vitro culture assay was used to determine whether $\gamma \delta \mathrm{T}$ cells secreted high levels of IL-6, and induced production of Th17 cells. The patients with ACI had significantly higher levels of IL-6 and $\gamma \delta \mathrm{T}$ cells. Furthermore, $\gamma \delta \mathrm{T}$ cells were associated with the secretion of a high level of IL- 6 in patients with ACI. These results indicate that $\gamma \delta \mathrm{T}$ cells are novel IL-6-secreting cells, which from then on were known as $\gamma \delta \mathrm{T} 6$ cells. In addition, the novel $\gamma \delta$ T6 cells induced Th17-cell production, and this induction was dependent on IL-6. Novel $\gamma \delta$ T6 cells increased the induction of Th17-cell production in patients with ACI. The results of the present study suggest that novel $\gamma \delta T 6$ cells may be a target for strategic therapies of ACI.
\end{abstract}

Correspondence to: Dr Wenli Hu, Department of Neurology, Beijing Chaoyang Hospital, Capital Medical University, The Worker's Stadium South Road, No. 8., Beijing 100020, P.R. China E-mail: huwenli@sina.com

Dr Renxi Wang, Laboratory of Immunology, Institute of Basic Medical Sciences, 27 Taiping Road, Beijing 100850, P.R. China E-mail: wang_renxi@yahoo.com

*Contributed equally

Key words: atherosclerotic cerebral infarction, interleukin-6, $\gamma \delta \mathrm{T}$ cells

\section{Introduction}

Stroke is a leading cause of death in the United States. Approximately $85 \%$ of strokes are ischemic and $15 \%$ are hemorrhagic. Cardioembolic stroke, microvascular disease and atherothrombosis are the three major etiologies of ischemic stroke (1). There are known to be two principal causes of atherosclerotic cerebral infarction (ACI): Atherosclerosis (AS) and plaque rupture (2). AS is a chronic inflammatory disease that involves various immune cells, particularly $\mathrm{T}$ lymphocytes, such as $\mathrm{CD}^{+} \mathrm{T}$-helper cells $(3,4)$. The increased production of T-helper (Th)17 cells, has previously been shown to be critical in the pathogenesis of AS and acute coronary syndrome $(5,6)$. Immune responses occur following acute ischemic stroke (7). A previous study recently demonstrated that Th17 cells may be increased in patients with ACI (8).

Pathological and intervention studies have implicated microorganisms in the initiation or maintenance of such inflammation $(9,10)$; however, there is also evidence that elevated concentrations of the acute phase reactant, C-reactive protein (CRP), may predict the development of clinical coronary heart disease over many years (11). These findings suggest that inflammation may contribute to the earlier stages of ACI. Furthermore, data from the Physicians' Health Study suggested that the beneficial effects of aspirin in reducing cardiovascular risk, are directly proportional to the degree of elevation of CRP (12), implicating a prostanoid-associated mechanism linking inflammation and atherothrombosis.

The hepatic synthesis of CRP is largely under the regulation of the proinflammatory cytokine interleukin (IL)-6 $(13,14)$. This cytokine is unusual, in that its major effects occur at sites distinct from its origin and are consequent upon its circulating concentrations (15). A previous report from the Rural Health Study demonstrated that elevated concentrations of IL-6 predict total and cardiovascular mortality over a 5-year follow-up, with the association being independent of prevalent vascular disease, smoking and traditional risk factors; and stronger than, but additive to, that for CRP. A study using animal models strongly suggested that IL- 6 may have a role in neuropathology (16). The present study showed that IL-6 
levels were increased in patients with ACI. Furthermore novel IL-6-expressing $\gamma \delta \mathrm{T}$ cells $(\gamma \delta \mathrm{T} 6$ cells) were identified in patients with ACI. These $\gamma \delta T 6$ cells were shown to induce Th17-cell production in an IL-6 dependent manner. The results of the present study suggest that the novel $\gamma \delta \mathrm{T} 6$ cells may be a target for strategic therapies of ACI.

\section{Materials and methods}

Patient population. The present study conformed to protocols approved by the Beijing Institute of Basic Medical Sciences Review Board (Beijing, China). The study was cross-sectional and blinded. The patients (50 male and 47 female) were examined at the Beijing Chaoyang Hospital and 307 Hospital (Beijing, China), where they were undergoing diagnostic catheterization, between May 2012 and July 2013. Ethical approval was obtained from the ethics committee of Beijing Institute of Basic Medical Sciences (Beijing, China) and informed consent was obtained from the patients, prior to commencement of the present study The patients were classified into two groups: Group 1, patients with ACI (22 males and 15 females; mean age, 56.6 \pm 9.9 years); group 2 , control subjects (28 males and 32 females; mean age, $54.3 \pm 11.1$ years), selected on the basis of recent angiography showing normal carotid arteries. The diagnotic criteria for ACI was modified from the Trial of Org 10172 in Acute Stroke Treatment (TOAST) criteria, based on the available clinical, radiographic and diagnostic information (17). There were no significant differences between the age ranges of the two groups.

None of the patients included in the present study were being treated with anti-inflammatory drugs and/or immunosuppressive agents. Furthermore, none of the patients suffered from subarachnoid hemorrhage, extradural or subdural hemorrhage, brain abscess, surgery or trauma, thromboembolism, disseminated intravascular coagulation, advanced liver disease, renal failure, malignant disease, other inflammatory disease, or chronic-immune-mediated disorders.

Blood samples. A total of $10 \mathrm{ml}$ peripheral blood (PB) was collected from each patient, in a fasting state, on the morning following admission. The time interval between the onset of symptoms and blood sampling was $<24 \mathrm{~h}$ in all cases. All of the samples were treated with sodium heparin and examined within $4 \mathrm{~h}$. PB mononuclear cells (PBMCs) were prepared by Ficoll density gradient for flow cytometric analysis and quantitative polymerase chain reaction (qPCR). Serum was obtained from the samples, following centrifugation $\left(900 \mathrm{x}\right.$ g at $4^{\circ} \mathrm{C}$ for $30 \mathrm{~min}$ ) and stored at $-80^{\circ} \mathrm{C}$ until further use.

qPCR analysis. Peripheral blood mononuclear cells qwew extracted for total RNA with TRIzol solution (Invitrogen Life Technologies). The final RNA pellets were dissolved in $0.1 \mathrm{mM}$ EDTA ( $2 \mu \mathrm{l} / \mathrm{mg}$ original wet weight). Reverse transcription reactions were carried out on $22 \mu \mathrm{l}$ of sample using superscript II RNAse H-Reverse Transcriptase (Invitrogen Life Technologies) in a reaction volume of $40 \mu 1$. All samples were diluted in $160 \mu \mathrm{l}$ nuclear-free water. qPCR was employed to quantify human IL-6 gene expression from the cDNA samples. Human IL-6 was designed using Primer Express version 1.0 software (Applied Biosystems) from the human
IL-6 gene sequences (GenBank/EBML databases; accession no. M54894; http://www.ncbi.nlm.nih.gov/nuccore/M54894). An 81 base-length IL- 6 fragment was amplified using the primers: forward 5'-GGTACATCCTCGAC-GGCATCT-3' and reverse 5'-GTGCCTCTTTGCTGC-TTTCAC-3'. TaqManfluorescent probe, 5'-FAM (6-carboxyfluorescein)TGTTACTCTTGTTACATGTCTCCTTTCTCAGGGCT-3'

TAMRA (6-carboxy-tetramethylrhodamine) (Applied Biosystems) was included with the primers in each reaction.

Measurement of blood biochemistry. Blood sugar and lipid levels were determined using an enzymatic method. High sensitive C-reactive protein was measured using an immunoturbidimetric method. All of the assays were conducted using an Olympus AU2700 biochemical autoanalyzer (Olympus Coporation, Tokyo, Japan).

Intracellular cytokine staining and flow cytometric analysis. The PBMCs $\left(1 \times 10^{6}\right.$ cells/sample) were washed with fluorescence-activated cell sorting staining buffer (phosphate-buffered saline, $2 \%$ fetal bovine serum or $1 \%$ bovine serum albumin, $0.1 \%$ sodium azide). All of the samples were incubated for $30 \mathrm{~min}$ at $4^{\circ} \mathrm{C}$ with $5 \mu \mathrm{g} / \mathrm{ml} 2.4 \mathrm{G} 2$ mouse anti-human Fc receptor monoclonal antibody (\#553142; BD Pharmingen, San Diego, CA, USA), prior to incubation for $30 \mathrm{~min}$ at $4^{\circ} \mathrm{C}$ with 1:100 diluted fluorochrome-conjugated mouse anti-human CD3 (\#17-0037), CD4 (\#11-0048), CD8

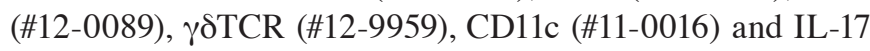
(\#12-7178) antibodies (eBioscience, Inc., San Diego, CA, USA), diluted in fluorescence-activated cell sorting (FACS) buffer supplemented with $2 \%$ anti-Fc receptor. For intracellular cytokine staining, $50 \mathrm{ng} / \mathrm{ml}$ phorbol myristate acetate and $1 \mathrm{mg} / \mathrm{ml}$ ionomycin (Sigma-Aldrich, St Louis, MO, USA) were added and the cells were incubated for a further $3 \mathrm{~h}$, following which $1 \mathrm{mg} / \mathrm{ml}$ brefeldin A and $2 \mathrm{mM}$ monensin were added. The cells were collected and fixed for $20 \mathrm{~min}$ with $1 \mathrm{ml}$ fixation buffer (Fix and Perm Cell Permeabilization kit; eBioscience). Following a further wash, the fixed cells were stained for $30 \mathrm{~min}$ at $4^{\circ} \mathrm{C}$ with 1:100 diluted fluorescein isothiocyanateconjugated mouse anti-human interferon (IFN) $\gamma$ (\#11-7319) and phycoerythrin-conjugated mouse anti-human IL-17 (\#127178) monoclonal antibodies (eBioscience, Inc., San Diego, CA, USA). The cells were incubated for $30 \mathrm{~min}$ at $4^{\circ} \mathrm{C}$ and were then washed twice and centrifuged $(402 \mathrm{x} \mathrm{g}$ for $10 \mathrm{~min}$ at $4^{\circ} \mathrm{C}$ ). Data collection and analysis were performed on a FACSCalibur $^{\mathrm{TM}}$ flow cytometer using CellQuest ${ }^{\mathrm{TM}}$ software (BD Biosciences, Franklin Lakes, NJ, USA).

Cytokine analysis by ELISA. The concentration of the cytokine IL-6 was measured using IL-6 ELISA kits (\#DY206-05; R\&D Systems, Inc., Minneapolis, MN, USA). Briefly, serum was collected by centrifuging the peripheral blood from healthy individuals or patients (402 x g for $30 \mathrm{~min}$ at room temperature). Subsequently, $100 \mu \mathrm{l}$ serum (1:10 dilution) was added in triplicate to a 96 -well plate for $1 \mathrm{~h}$ at $37^{\circ} \mathrm{C}$. The plates were then washed and biotin rat anti-human IL- 6 monoclonal antibody (5 $\mu \mathrm{g} / \mathrm{ml}$; \#840114; R\&D Systems, Inc.) was added to the plates, followed by a further incubation for $1 \mathrm{~h}$ at $37^{\circ} \mathrm{C}$. The unbound antibodies were removed by washing. The plates were subsequently incubated with avidin-HRP (1:1,000 dilution) for $1 \mathrm{~h}$ 
at $37^{\circ} \mathrm{C}$. All of the antibodies were obtained from eBioscience. The color was visualized by incubation for $15 \mathrm{~min}$ at room temperature with o-phenylenediamine, and the optical density was measured at $492 \mathrm{~nm}$, with an ELISA reader (Bio-Rad Laboratories, Inc., Hercules, CA, USA). Standard curves were established to quantitate the amount of the respective cytokines.

$\gamma \delta$ T cell sorting and co-culture with $C D 4^{+} T$ cells. $\gamma \delta T$ cells were sorted based on CD3 and $\gamma \delta$ TCR staining of the samples taken from the controls and the patients with ACI, by flow cytometry (purity $>95$ ). $\mathrm{CD}^{+} \mathrm{T}$ cells, obtained from the controls, were cultured for 4 days at $37^{\circ} \mathrm{C}$ in plates coated with $3 \mu \mathrm{g} / \mathrm{ml}$ mouse anti-human CD3 monoclonal antibody (\#16-0037), and media containing $2 \mu \mathrm{g} / \mathrm{ml}$ mouse anti-human CD28 monoclonal antibody (\#16-0289) (eBioscience, Inc.), in the presence of $\gamma \delta T$ cells from controls or patients with ACI $\left(\mathrm{CD}^{+} \mathrm{T}\right.$ cells : $\gamma \delta \mathrm{T}$ cells, 4:1). To detect the role of IL-6 in $\gamma \delta T$ cells-induced Th17 cell production, neutralizing mouse anti-human gp130 (IL-6 receptor) monoclonal antibody (50 $\mu \mathrm{g} / \mathrm{ml}$; \#MAB228; R\&D Systems, Inc.) was added to the plates and cells were cultured for 3 days at $37^{\circ} \mathrm{C}$.

Statistical analysis. Statistical significance of the differences between the groups was determined using a t-test. Statistical analyses were performed using GraphPad Prism version 5.0 (GraphPad Software Inc., La Jolla, CA, USA). The values are represented as the means \pm standard deviation. The coefficients of determination $\left(\mathrm{r}^{2}\right)$ were calculated in order to evaluate the correlation between the clinical score with histological pathological features. A $\mathrm{P}<0.05$ was considered to indicate a statistically significant difference.

\section{Results}

Patients and controls. There were no significant differences in the age, gender, hypertension, smoking rate, high density lipoprotein-cholesterol and very low density lipoprotein-cholesterol concentrations between the two groups. The fasting blood glucose, total cholesterol and total triglyceride levels were significantly higher in the patients with ACI, as compared with the control groups $(\mathrm{P}<0.05$ and $\mathrm{P}<0.01$, respectively; Table I).

IL-6 levels are increased in patients with ACI. ACI is thought to be a chronic inflammatory disease, and IL-6 may have a key role in inducing the inflammatory response through various mechanisms. Therefore, the levels of IL- 6 were determined in the serum samples taken from the healthy controls and patients with ACI, by ELISA assay. The patients with ACI had significantly higher levels of IL-6, as compared with the healthy controls (Fig. 1).

$\gamma \delta T$ cells are increased in patients with ACI. To explore which population of cells induced IL-6 in the patients with ACI, the immune cells were analyzed by flow cytometry. PB cells were collected from both the healthy controls and patients with ACI. The lymphocytes were sorted from the PB cells using Lymphocyte Separation solution (LTS1077; Tina Jin Hao Yang Biol Co, Ltd., Tianjing, China). Fluorochrome-conjugated anti-human CD3, CD4, $\gamma \delta T C R, C D 8, C D 11 c$ were used to stain the cells. A FACS analysis showed that the patients with
Table I. Patient characteristics.

\begin{tabular}{lcc}
\hline Characteristic & Control $(\mathrm{n}=60)$ & ACI $(\mathrm{n}=37)$ \\
\hline Age (years) & $54.3 \pm 11.1$ & $56.6 \pm 9.9$ \\
Gender (male/female) & $28 / 32$ & $22 / 15$ \\
Hypertension, $\mathrm{n}(\%)$ & $27(45)$ & $18(48.6)$ \\
Smoking rate, $\mathrm{n}(\%)$ & $36(60)$ & $23(62.2)$ \\
FBG $(\mathrm{mmol} / \mathrm{l})$ & $4.54 \pm 0.32$ & $4.79 \pm 0.58^{\mathrm{a}}$ \\
TC $(\mathrm{mmol} / \mathrm{l})$ & $4.17 \pm 0.12$ & $5.46 \pm 0.57^{\mathrm{b}}$ \\
TG $(\mathrm{mmol} / \mathrm{l})$ & $1.24 \pm 0.21$ & $1.52 \pm 0.35^{\mathrm{a}}$ \\
HDL-C (mmol/l) & $1.37 \pm 0.15$ & $1.27 \pm 0.17$ \\
LDL-C (mmol/l) & $2.62 \pm 0.47$ & $2.83 \pm 0.73$ \\
VLDL-C (mmol/l) & $0.53 \pm 0.29$ & $0.59 \pm 0.34$ \\
\hline
\end{tabular}

Values are expressed as the means \pm standard deviation, or number (n). ACI, atherosclerotic cerebral infarction; FBG, fasting blood glucose; TC, total cholesterol; TG, total triglyceride; HDL-C, high-density lipoprotein-cholesterol; LDL-C, low density lipoprotein-cholesterol; VLDL-C, very low density lipoprotein-cholesterol. ${ }^{\mathrm{a}} \mathrm{P}<0.05,{ }^{\mathrm{b}} \mathrm{P}<0.01$ vs. the controls.

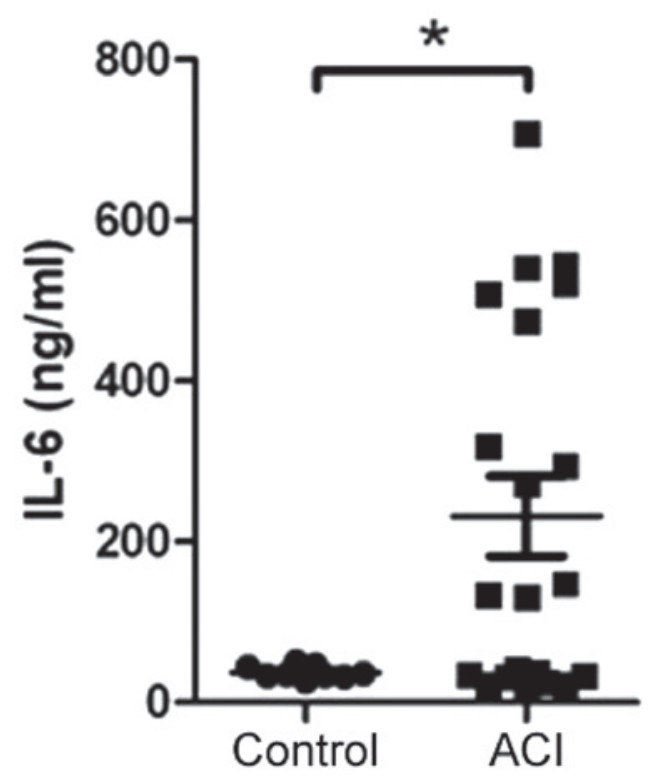

Figure 1. Levels of interleukin (IL)-6 were increased in the serum samples of patients with atherosclerotic cerebral infarction (ACI). The serum was collected from 60 controls and 37 patients with ACI, and the IL-6 levels were determined by ELISA. ${ }^{*} \mathrm{P}<0.05$ vs the controls. The data represents the results of at least three independent experiments.

$\mathrm{ACI}$ had slightly reduced percentages of $\mathrm{CD}^{+}, \mathrm{CD}^{+}, \mathrm{CD}^{+} \mathrm{T}$ cells, as compared with the healthy controls. The percentage of CD11 $\mathrm{c}^{+}$dendritic cells (DC) was significantly decreased in the patients with ACI. The percentage of $\gamma \delta$ T cells was $0.5 \%$ and $2.3 \%$ in the PBMCS of the healthy controls and patients with ACI, respectively (Fig. 2). These results suggest that $\gamma \delta$ T cells are significantly increased in patients with ACI.

$\gamma \delta T$ cells secrete high levels of IL-6. The levels of IL-6 and the percentage of $\gamma \delta \mathrm{T}$ cells were compared in the patients 
A
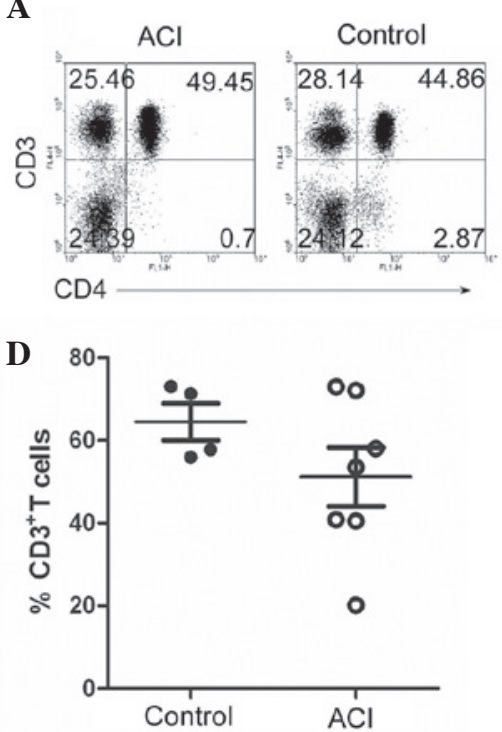

G

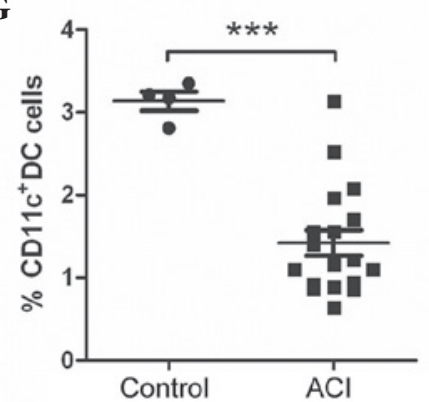

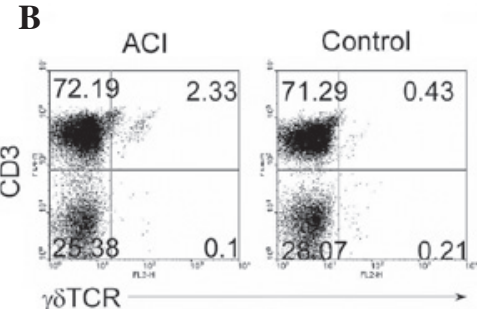
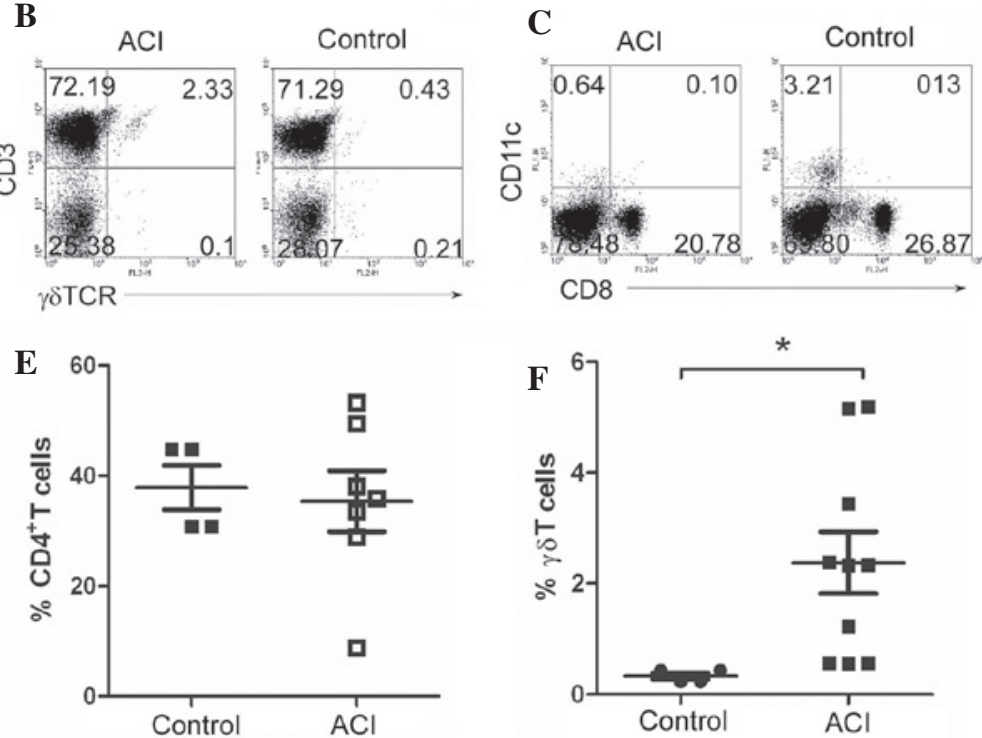

Figure 2. $\gamma \delta \mathrm{T}$ cells increased in patients with atherosclerotic cerebral infarction (ACI). Peripheral blood mononuclear cells (PBMCs) were prepared by Ficoll density gradient, from 60 control and 37 patients with ACI. Fluorochrome-conjugated anti-human CD3, (A) CD4, (B) $\gamma \delta T C R, ~ C D 8,(C)$ CD11c antibodies were used to stain the cells. The cells were analyzed by flow cytometry, the numbers in the quadrants indicate the percentages of (D) $\mathrm{CD} 3^{+},(\mathrm{E}) \mathrm{CD}^{+},(\mathrm{F}) \gamma \delta \mathrm{T}^{+}$, (G) $\mathrm{CD}^{+}-\mathrm{T}$ or $(\mathrm{H}) \mathrm{CD}_{11 \mathrm{c}^{+}}$dendritic cells. ${ }^{*} \mathrm{P}<0.05 ;{ }^{* * *} \mathrm{P}<0.001$, vs the controls.. The data represents the results of at least four independent experiments.

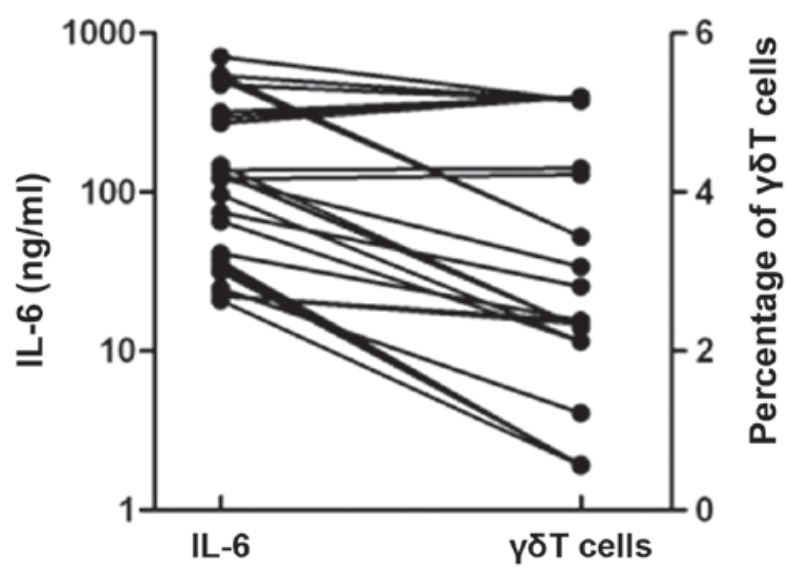

Figure 3. Interleukin (IL)-6 is positively associated with $\gamma \delta \mathrm{T}$ cells in patients with atherosclerotic cerebral infarction (ACI). IL-6 levels and the percentage of $\gamma \delta \mathrm{T}$ cells were analyzed in $37 \mathrm{ACI}$ patients, by individual match.

with ACI. IL-6 was positively associated with $\gamma \delta$ T cells in the patients with ACI (Fig. 3).

To determine whether $\gamma \delta \mathrm{T}$ cells secreted high levels of IL-6 in the PBMC from patients with ACI, $\gamma \delta \mathrm{T}$ cells were sorted, from both groups, by flow cytometry and IL- 6 expression levels were determined by qPCR. The $\gamma \delta \mathrm{T}$ cells from

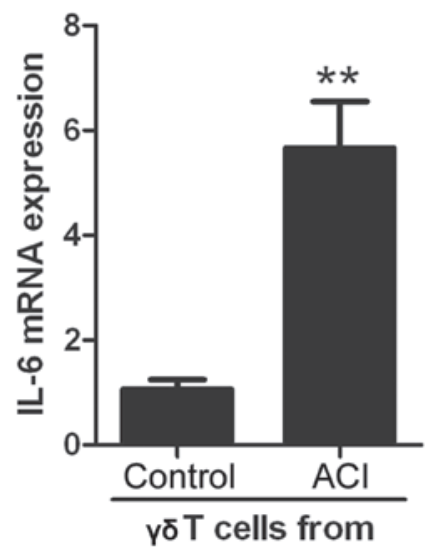

Figure 4. $\gamma \delta$ T cells secreted high levels of interleukin (IL)-6 in patients with atherosclerotic cerebral infarction (ACI). Peripheral blood mononuclear cells (PBMCs) were prepared by Ficoll density gradient, from 60 control and 37 patients with ACI. $\gamma \delta \mathrm{T}$ cells were stained with anti-human CD3 and $\gamma \delta \mathrm{TCR}$ antibody, sorted by fluorescence-activated cell sorting from PBMCs, and subjected to quantitative polymerase chain reaction. The data represents at the results of at least four independent experiments. Error bars represent standard error of the mean. $* * \mathrm{P}<0.01$, vs. the controls.

the PBMC of the patients with ACI significantly increased IL-6 expression levels, as compared with the controls (Fig. 4). These results suggest that $\gamma \delta \mathrm{T}$ cells are novel IL-6-expressing 
A

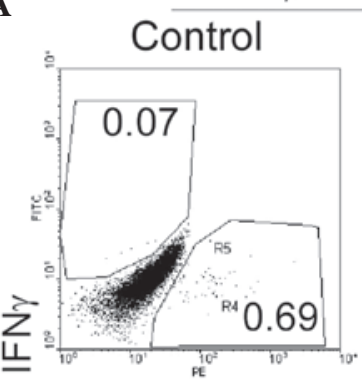

IL-17 $\gamma \delta$ T cells from

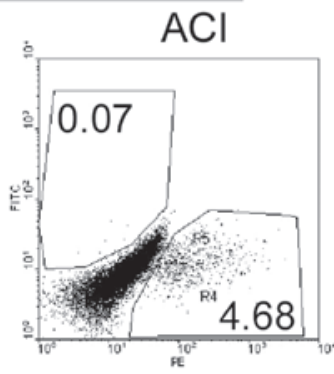

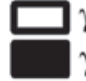
$\gamma \delta \mathrm{T}$ cells from control $\gamma \delta \mathrm{T}$ cells from $\mathrm{ACl}$

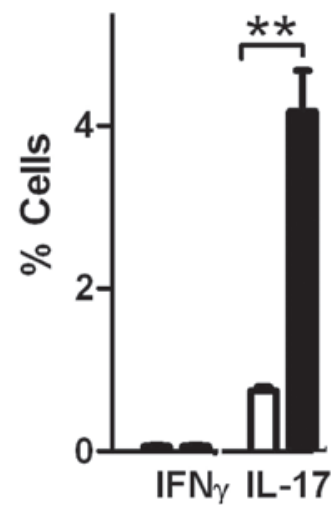

Figure 5. Interleukin (IL)-6-expressing $\gamma \delta$ T cells induced T-helper (Th)17 cell production. (A) Peripheral blood mononuclear cells (PBMCs) were prepared by Ficoll density gradient, from 60 control and 37 patients with atherosclerotic cerebral infarction (ACI). The $\gamma \delta \mathrm{T}$ cells were sorted by fluorescence-activated cell sorting from PBMCs and co-cultured for 4 days with $\mathrm{CD} 4^{+} \mathrm{T}$ cells. Fluorochrome-conjugated anti-human interferon (IFN) $\gamma$, IL-17 and CD4 antibodies were used to stain the cells. The cells were gated on CD4 with numbers in quadrants indicating the percentage of IFN $\gamma^{+} \mathrm{Th} 1$ and IL-17 $\mathrm{Th} 17$ cells. (B) Quantification of the percentage of the cells. The data represents the results of at least three independent experiments Error bars represent standard error of the mean. ** $\mathrm{P}<0.01$, vs. the controls.

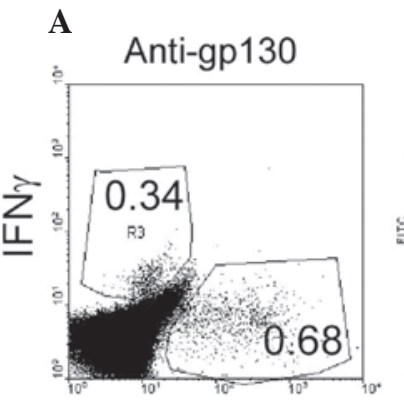

IL-17

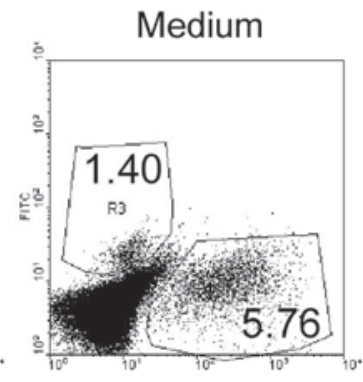

5.76

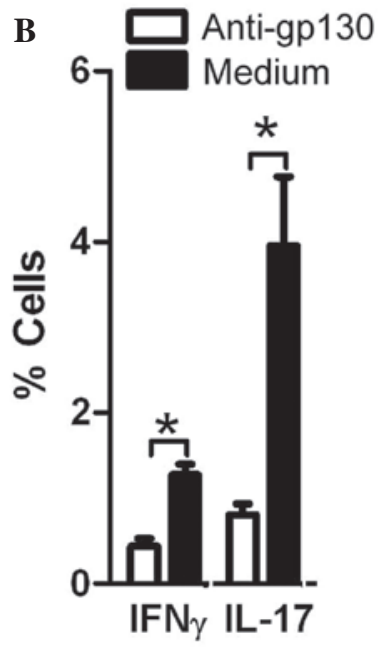

Figure 6. $\gamma \delta \mathrm{T}$ cells in patients with atherosclerotic cerebral infarction (ACI) induced T-helper (Th)17 cell production in an interleukin (IL)-6 dependent manner. (A) Peripheral blood mononuclear cells (PBMCs) were prepared by Ficoll density gradient, from 37 ACI patients. $\gamma \delta \mathrm{T}$ cells were sorted by fluorescence-activated cell sorting from PBMCs , and co-cultured for 4 days with CD4 ${ }^{+} \mathrm{T}$ cells, in the presence of $50 \mu \mathrm{g} / \mathrm{ml}$ neutralizing anti-gp130 (IL-6 receptor) antibody. Fluorochrome-conjugated anti-human interferon (IFN) $\gamma$, IL-17 and CD4 antibodies were used to stain the cells. The cells were gated on CD4 with numbers in quadrants indicating percentage of IFN $\gamma^{+} \mathrm{Th} 1$ and IL- $17^{+}$Th17 cells. (B) Quantification of the percentage of the cells. The data represents the results of at least three independent experiments. Error bars represent standard error of the mean. ${ }^{* *} \mathrm{P}<0.01$, vs. the control medium.

cells. Following this finding, these cells were known as $\gamma \delta T 6$ cells.

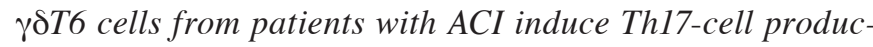
tion. A recent study demonstrated that Th17 cells are increased in patients with ACI (8). To determine the role of $\gamma \delta \mathrm{T}$ cells in Th17-cell production, $\gamma \delta \mathrm{T}$ cells, from both controls and patients with ACI, were co-cultured with $\mathrm{CD}^{+}{ }^{+} \mathrm{T}$ cells obtained from the controls. Following 4 days of culture, the cells were collected and stained. The percentage of interferon (IFN) $\gamma^{+} \mathrm{CD} 4{ }^{+} \mathrm{Th} 1$ cells was unchanged; however, co-culture with the $\gamma \delta \mathrm{T}$ cells from the patients with ACI significantly increased the levels of $1 \mathrm{~L} 17^{+} \mathrm{CD} 4{ }^{+} \mathrm{Th} 17$ cells (Fig. 5). These results suggest that $\gamma \delta \mathrm{T} 6$ cells may be key pro-inflammatory mediators in patients with ACI.

$\gamma \delta T 6$ cells in ACI patients induce Th17-cell production in an IL-6 dependent manner. To study the role of IL-6 in $\gamma \delta T 6$-induced Th17-cell production, neutralizing anti-gp130 Abs were added to the co-cultured $\gamma \delta \mathrm{T}$ and $\mathrm{CD} 4^{+} \mathrm{T}$ cells. Following 4 days of culture, the cells were collected and stained. The percentage of $\mathrm{IFN} \gamma^{+} \mathrm{CD} 4^{+} \mathrm{Th} 1$ cells remained 
unchanged. The incubation with anti-gp130 significantly reduced the production of the $\mathrm{IL} 17^{+} \mathrm{CD} 4^{+} \mathrm{Th} 17$ cells upregulated by $\gamma \delta \mathrm{T} 6$ cells (Fig. 6). These results suggest that $\gamma \delta \mathrm{T}$ cells in patients with ACI induce Th17-cell production, in an IL-6 dependent manner.

\section{Discussion}

Risk factors of cerebral infarction (CI) are similar to those associated with atherosclerosis, including diabetes, tobacco smoking, hypercholesterolemia, hyperlipoproteinemia, high blood pressure and obesity (1). There is mounting evidence that inflammation has a role in the development of CI. Observations have previously been made linking the presence of infections in the vessel wall with atherosclerosis, and epidemiological data has also implicated infection in remote sites, in the aetiology of CI (18). Inflammation leads to localized recruitment of neutrophils and monocytes, and the presence of activated macrophages in the cap of atherosclerotic plaques (19) has led to suggestions that they may contribute to plaque rupture, through effects on matrix metalloproteinases (20). The present study demonstrated that levels of IL- 6 were increased in the serum from patients with ACI. These data suggest that IL-6 may be an important mechanistic link between various risk factors, including obesity, occupational stress, and ACI. This may have clinical implications.

Numerous studies have suggested that IL-6 is derived from immune cells and is an important determinant of acute phase activation $(15,21)$. In the present study, in order to detect which population of cells induced IL-6 secretion, various immune cells were examined. The $\gamma \delta \mathrm{T}$ cells, but not the other common immune cells $\mathrm{CD}^{+} \mathrm{T}, \mathrm{CD} 4^{+} \mathrm{T}, \mathrm{CD} 8^{+} \mathrm{T}, \mathrm{CD} 11 \mathrm{c}^{+} \mathrm{DC}$, were shown to be increased in the PBMC from patients with ACI. This finding suggests that $\gamma \delta \mathrm{T}$ cells may have an important role in the induction of ACI. Previous data obtained from experimental models of induced autoimmunity, support the idea that $\gamma \delta \mathrm{T}$ cells, in a niche-restricted manner, accelerate and enhance the response of tissue antigen-specific T-helper cells. The function of $\gamma \delta \mathrm{T}$ cells may be particularly relevant at epithelial surfaces and, perhaps, in neuroectodermal tissue (22, 23). The functional relevance of $\gamma \delta \mathrm{T}$ cells in humans has yet to be elucidated. It has previously been suggested that $\gamma \delta \mathrm{T}$ cells directly shape the inflammatory infiltrate, for example, by attracting neutrophils (22).

In the present study, the levels of IL-6 were shown to be positively associated with $\gamma \delta \mathrm{T}$ cells in the patients with ACI, and the $\gamma \delta$ T cells from the patients with ACI, significantly increased the expression levels of IL-6. $\gamma \delta \mathrm{T}$ cells are increasingly being recognized as having important functional roles in various disease scenarios, including infection, allergy, autoimmunity and cancer (22). It has therefore been hypothesized that $\gamma \delta \mathrm{T}$ cells are not a homogenous population of cells with a single physiological role. Instead, ever increasing complexity, in both phenotype and function, is being ascribed to $\gamma \delta \mathrm{T}$ cells subsets from various tissues and locations, both in mice and humans (23). Furthermore, similar to $\mathrm{CD}^{+} \mathrm{T}$ helper cells, subsets of $\gamma \delta \mathrm{T}$ cells can be defined based on distinct cytokine profiles, with IFN- $\gamma$-producing $(\gamma \delta \mathrm{T} 1)$ and IL-17-producing $\gamma \delta \mathrm{T}(\gamma \delta \mathrm{T} 17)$ cells having distinct functional phenotypes.
The expression of natural killer 1.1 and CD27, as compared with Scart-2 and C-C chemokine receptor-6, depends on the commitment of $\gamma \delta \mathrm{T}$ cells to produce IFN- $\gamma$ and IL-17, respectively. The present study identified a novel subset of IL-6-expressing $\gamma \delta \mathrm{T}$ cells: $\gamma \delta \mathrm{T} 6$.

To further explore the function of the novel $\gamma \delta \mathrm{T} 6$ cells, $\gamma \delta \mathrm{T}$ cells from controls and patients with ACI were co-cultured with $\mathrm{CD} 4^{+} \mathrm{T}$ cells obtained from the controls. The $\gamma \delta \mathrm{T} 6$ cells induced the production of the pathogenic IL-17+Th17 cells. Furthermore, these data suggest that $\gamma \delta \mathrm{T} 6$ cells from patients with ACI induced Th17-cell production, dependent on IL-6. In murine models it has previously been demonstrated that mice with decreased IL-17 levels develop fewer lesions, and increases in the levels of IL-17 may enhance early lesion formation. These data suggest a potential role for Th17 cells in the promotion of atherogenesis (24). In human lesions, Th17 may participate in the inflammatory process of plaque rupture (25). Therefore, Th17 has been hypothesized to have a role in the development and complications of atherosclerosis.

Recent findings have demonstrated that a numeral and functional imbalance of Th17/Treg cells exists in patients with ACI, suggesting a potential role for the imbalance of these cells in the onset of ACI (25). Oxidized-low-density lipoprotein may contribute to plaque destabilization and rupture by its effects on this balance (25). The imbalance of Th17/Treg cells appears to be a novel target for research on the pathogenesis and treatment of ACI.

In conclusion, the present study identified a novel IL-6-expressing $\gamma \delta \mathrm{T}$ subset: $\gamma \delta \mathrm{T} 6$, which were increased in patients with ACI. These $\gamma \delta \mathrm{T} 6$ cells efficiently induced Th17-cell production. The results of the present study suggest that $\gamma \delta \mathrm{T} 6$ cells may be a target for strategic therapies in $\mathrm{ACI}$ patients.

\section{Acknowledgements}

The present study was supported by the National Basic Research Program 973 Grants (no. 2013CB530506), Beijing Natural Science Foundation (nos. 7132139 and 7132151) and National Nature and Science Fund (nos. 81272320 and 81172800).

\section{References}

1. Weinberger J: Diagnosis and prevention of atherosclerotic cerebral infarction. CNS Spectr 10: 553-564, 2005.

2. Parmar JP, Rogers WJ, Mugler JP III, et al: Magnetic resonance imaging of carotid atherosclerotic plaque in clinically suspected acute transient ischemic attack and acute ischemic stroke. Circulation 122: 2031-2038, 2010.

3. Binder CJ, Chang MK, Shaw PX, et al: Innate and acquired immunity in atherogenesis. Nat Med 8: 1218-1226, 2002.

4. Hansson GK and Libby P: The immune response in atherosclerosis: a double-edged sword. Nat Rev Immunol 6: 508-519, 2006.

5. Li Q, Wang Y, Chen K, et al: The role of oxidized low-density lipoprotein in breaking peripheral Th17/Treg balance in patients with acute coronary syndrome. Biochem Biophys Res Commun 394: 836-842, 2010.

6. Xie JJ, Wang J, Tang TT, et al: The Th17/Treg functional imbalance during atherogenesis in ApoE(-/-) mice. Cytokine 49: 185-193, 2010.

7. Haeusler KG, Schmidt WU, Foehring F, et al: Immune responses after acute ischemic stroke or myocardial infarction. Int J Cardiol 155: 372-377, 2012.

8. Li Q, Wang Y, Yu F, et al: Peripheral Th17/Treg imbalance in patients with atherosclerotic cerebral infarction. Int J Clin Exp Pathol 6: 1015-1027, 2013. 
9. Patel P, Mendall MA, Carrington D, et al: Association of Helicobacter pylori and Chlamydia pneumoniae infections with coronary heart disease and cardiovascular risk factors. BMJ 311: 711-714, 1995.

10. Kuo CC, Gown AM, Benditt EP and Grayston JT: Detection of Chlamydia pneumoniae in aortic lesions of atherosclerosis by immunocytochemical stain. Arterioscler Thromb 13: 1501-1504, 1993.

11. Kuller LH, Tracy RP, Shaten J and Meilahn EN: Relation of C-reactive protein and coronary heart disease in the MRFIT nested case-control study. Multiple Risk Factor Intervention Trial. Am J Epidemiol 144: 537-547, 1996.

12. Ridker PM, Cushman M, Stampfer MJ, Tracy RP and Hennekens CH: Inflammation, aspirin, and the risk of cardiovascular disease in apparently healthy men. New Engl J Med 336: 973-979, 1997.

13. Bataille R and Klein B: C-reactive protein levels as a direct indicator of interleukin-6 levels in humans in vivo. Arthritis Rheum 35: 982-984, 1992.

14. Heinrich PC, Castell JV and Andus T: Interleukin-6 and the acute phase response. Biochem J 265: 621-636, 1990.

15. Harris TB, Ferrucci L, Tracy RP, et al: Associations of elevated interleukin-6 and C-reactive protein levels with mortality in the elderly. Am J Med 106: 506-512, 1999.

16. Erta M, Quintana A and Hidalgo J: Interleukin-6, a major cytokine in the central nervous system. Int J Biol Sci 8: 1254-1266, 2012.
17. Fure B, Wyller TB and Thommessen B: TOAST criteria applied in acute ischemic stroke. Acta Neurol Scand 112: 254-258, 2005.

18. Yudkin JS, Kumari M, Humphries SE and Mohamed-Ali V: Inflammation, obesity, stress and coronary heart disease: is interleukin-6 the link? Atherosclerosis 148: 209-214, 2000.

19. Alexander RW: Inflammation and coronary artery disease. N Engl J Med 331: 468-469, 1994.

20. Galis ZS, Sukhova GK, Lark MW and Libby P: Increased expression of matrix metalloproteinases and matrix degrading activity in vulnerable regions of human atherosclerotic plaques. J Clin Invest 94: 2493-2503, 1994.

21. Tappia PS, Troughton KL, Langley-Evans SC and Grimble RF: Cigarette smoking influences cytokine production and antioxidant defences. Clin Sci (Lond) 88: 485-489, 1995.

22. Korn T and Petermann F: Development and function of interleukin 17-producing $\gamma \delta T$ cells. Ann NY Acad Sci 1247: 34-45, 2012.

23. Pang DJ, Neves JF, Sumaria N and Pennington DJ: Understanding the complexity of $\gamma \delta$ T-cell subsets in mouse and human. Immunology 136: 283-290, 2012.

24. Song L and Schindler C: IL-6 and the acute phase response in murine atherosclerosis. Atherosclerosis 177: 43-51, 2004.

25. Hashmi S and Zeng QT: Role of interleukin-17 and interleukin-17-induced cytokines interleukin-6 and interleukin-8 in unstable coronary artery disease. Coron Artery Dis 17: 699-706, 2006. 